\title{
DUCH TIAŽE J. L. FISCHERA
}

JOZEF LYSÝ, Univerzita Komenského v Bratislave, Pedagogická fakulta, Katedra etickej a občianskej výchovy, Bratislava, SR

LYSÝ, J.: The Spirit of Weight in J. L. Fischer

FILOZOFIA, 76, 2021, No 3, pp. $167-180$

The paper discusses the topic of democracy contained in the philosophical concept of Josef Ludvík Fischer (1894 - 1973). The starting point is the idea of respect to the Order of Reality flowing into the theory of ,structural democracy“. J. L. Fisher eventually arrives at the questions of freedom, the topic of our options to re-create reality, depending on our desire, on our heroism, and on the type of perfect order we are willing to create.

Keywords: Spirit of weight - Democracy - Crisis - Order - Reality

\section{Úvod}

V modernej dobe sa pojem demokracie používa univerzálne, ale konsenzus v súvislosti s jeho interpretáciou nebol dosiahnutý. Na začiatku dvadsiateho prvého storočia je situácia zložitejšia v dôsledku minulého vývoja (vojny, dekolonizácia, nerovnomerný ekonomický a politický vývoj atd'.), ale aj v súčasnosti prebiehajúcimi procesmi rozširovania demokracie vo svete. $\mathrm{V}$ posledných desat'ročiach sme boli svedkami rôznych farebných revolúcií ohlasujúcich demokraciu. Otvoril sa priestor pre slobodu a rovnoprávnost' jednotlivcov pri tvorbe formálnych pravidiel prijímania mocenských rozhodnutí a formulovaní ciel'ov. Legitimita rozhodnutí sa mala opierat' o slobodu úpadku jednotlivca v pluralitnej spoločnosti. Súčastou týchto procesov bolo zriad’ovanie adekvátnych inštitúcií v priaznivej politickej kultúre. Zároveň sme svedkami oslabovania legitimity demokratických inštitúcií, politických strán, nárastu populizmu, oslabovania sociálneho štátu, tvrdohlavého presadzovania neoliberálnych reforiem napriek odporu občanov.

Európsky politický a sociálny vývoj na počiatku novoveku vytvoril civilný étos buržoázie. Zároveň ho však zat’ažil dogmou o kvantitatívnej povahe súcna, ktorá sa stala podl'a Josefa Ludvika Fischera zdrojom problematických koncepcií novovekej racionality, ktoré viedli k neadekvátnemu postihovaniu spoločenskej reality všeobecne a k politickej kríze, predovšetkým kríze demokracie a parlamentarizmu zvlášt'. Myslitel', ktorý sa ocitne v tomto kontexte, si bezpochyby zaslúži pozornost'. Najmä 
ak ide o filozofický systém so špecifickým kategoriálnym noetickým a ontologickým aparátom. Obidva kontexty spíňa filozofické dielo Josefa Ludvíka Fischera, ktorý obidva póly spojil do pôvodnej univerzalistickej koncepcie. Touto intenciou sa zarad’uje medzi významných predstavitel’ov českej filozofie. Sám konštatuje, že „uvedenie funkcionalizmu a štrukturalizmu do českej filozofie a sociológie je späté s mojím menom“ (Fischer 1968, 69). Z množiny problémových intencií jeho filozofického odkazu sa bližšie sústredíme na jeho l'udský a občiansky postoj vo vzt'ahu k jeho analýze demokracie. Písal o nej v čase, ktorý pre ňu nebol priaznivý.

J. L. Fischer sa stretáva s dvoma svetmi vedenia, v ktorých je funkcia starej skúsenosti konfrontovaná so skutočnost'ou a posilňovaná osobným postojom, ktorý vyúst'uje do praxe, z ktorej nemôžeme utiect' bez rozuzlenia témy objektivity. Pre Fischera je filozofia „náukou o zvládnutí skutočnosti“. Jeho koncept je vedome protipozitivistický. Poriadok znamená vnútornú skladbu sveta a skutočnosti, poznania a človeka, pričom jednota je dokonca horizontálne a vertikálne hierarchicky členená štruktúra (Fischer 1933, 219). Krízu demokracie Fischer vysvetl'uje noeticky. Vedeckost' filozofie znamená, že jej témou je veda, a Fischer napokon postavenie filozofie vníma ako metateóriu. Ak zoberieme do úvahy, že časovo sa pohybujeme v dvadsiatych a tridsiatych rokoch minulého storočia, tak podl'a L. Valentu sa Fischer prepracoval k pojmu ,zmysel“, v ktorom zmysel je poznanou skutočnost'ou, teda musia byt' vo vzájomnom vzt'ahu. Uniknút' lineárnej epistemológii, ako doložil vývoj svetovej filozofie od tridsiatych rokov minulého storočia, možno spojením zmyslu a jazyka. Fischer sa dostal na prah tohto postupu (Valenta 2017, 24).

\section{Vedecká a prežívaná demokracia}

J. L. Fischer si bol vedomý, že každý pokus o vedecký výklad takých pálčivých otázok ako politická problematika je spojený s rizikom dokonale nevedeckým. Pre mnohých bolo nepochopitel'né, že by demokracia mohla byt' v kríze... Na druhej strane úpadku demokracie nezabránia žiadne mocenské opatrenia, ale iba odstránenie príčin, ktoré ho privodili... „O mnohých otázkach sa nevyjadrujem prvýkrát“ (Fischer 1933, 8). Výsledkom má byt' syntéza sústavy definícií, ktoré pre svoju abstraktnost' budú robit' t’ažkosti čitatel'ovi, ktorý si nezvykol na pojmové myslenie. Knihu Kriza demokracie venoval F. X. Šaldovi, ktorý vyrástol z pôdy českej národnej tradície do výšin kultúrneho európanstva.

Genézu krízy demokracie nachádza v nástupe novoveku, ked’ sa presadil „,merajúci“ rozum, ktorým sa sociálna skutočnost' nedá zvládnut', pretože nie je meratel'nou skutočnost'ou. Vtedy novoveký typ racionality vypracoval pre náš spôsob videnia sveta systém kategórií, centralizovaný okolo kategórie kvantity, vzt’ahu a príčinnosti. Václav Černík - podobne ako Fischer - zdôrazňuje, že základom klasickej koncepcie 
merania sa stal pojem veličiny. „Pomocou matematickej funkcie a funkcionálnych rovníc sa veda zmocňuje zákonitostí pohybu... prostredníctvom funkcionálnej rovnice možno vyjadrit' zákon idealizovaného pohybu, ktorý zjednocuje pluralitu pozorovaných pohybov a zmien. Ako klasický príklad môže slúžit' Galileiho zákon vol'ného pádu“ (Černík, Viceník, Višňovský 1997, 101). Fischer novoveký typ racionality po kategoriologickej analýze symbolicky charakterizuje ako duch tiaže, kým napríklad Černík v tom vidí šancu pre neklasický typ racionality. Zmena začala kantovsko-laplaceovskou hypotézou, ktorá označila poklasickú vývinovú fázu novovekého typu racionality, v ktorej sa „newtonovská paradigma výrazne konfrontovala s antimechanistickým prúdom vedeckého poznania“(Černík, Viceník, Višňovský 1997, 98).

J. L. Fischer „merajúci rozum“ analyticky, názorne ukázal na chybách Rousseauových politických postulátov. Vlastným zmyslom demokracie je „spočítavajúci volebný mechanizmus" ako prejav neomylnej vôle l'udu. To je základná príčina toho, čo nazýva krízou demokracie. Druhú príčinu krízy demokracie identifikoval v nedostatkoch zastupitel'ského systému, ktorý bude kolabovat' pod tiažou d'alších a d'alších úloh a funkcií spoločnosti. Napokon parlamentné zriadenie priviedlo k životu špecifický orgán spojený so správou spoločnosti, štátnu administratívu, byrokraciu, ktorá preklenula bezmocné parlamentárne zriadenie (Fischer 1932, 73). Avšak vyviest' demokraciu z nedôstojného postavenia je možné.

Demokracia pre Fischera znamená viac ako liberálna prax. Európa sa teda ocitla v kríze spôsobenej dynamicko-kvantitatívnym charakterom európskej kultúry. Už koncom dvadsiatych rokov minulého storočia bola situácia hraničná (taliansky fašizmus a nastupujúci nacizmus v Nemecku). Napriek silne kritickému hl'adisku voči tomu, ako sa demokracia uskutočňovala v Spojených štátoch a v Európe vrátane Československa, nikdy nespochybnil jej „demokratický postulát“. Fischerov demokratický postulát zahrnoval civilný étos, politickú autonómiu l’udu, konsenzus vlády so spoločenskou všeobecnou vôl'ou, slobodou presvedčenia, s individuálnym a sociálnym sebaurčením atd'. Predovšetkým je demokracia takou formou politickej organizácie spoločnosti, $v$ ktorej je aktívnym subjektom, a nie pasívnym objektom. Spoločnost' v demokracii vyhlasuje právo rozhodovat' o každom možnom vládnom programe, nevyhlasuje však žiadny „,v̌̌eobecný demokratický program“, aby sa vždy príležitostne rozhodovala pre nejaký skutočný program. Demokratickým postulátom sú určité podmienky, ktoré musí splnit' každá vláda, ak má byt' demokratickou. Rozsah týchto podmienok je daný úrovňou politického vedomia, určeného vedomím politickej svojprávnosti. Spoločnost' je podl'a J. L. Fischera demokratická vtedy, ked' si jednotlivé jej vrstvy uvedomili túto svojprávnost'. Tento proces je správnejšie pomenovat' ako demokratizácia spoločnosti, ktorá prebieha postupne. Demokratickým sa toto úsilie stáva vtedy, ked’ je vyhlásená rovnost' práv pre všetky vrstvy. Demokratický 
postulát je politická rovnoprávnost' všetkých politicky uvedomelých vrstiev spoločnosti, ktorá sa prejavuje ich politickou svojprávnost'ou, autonómiou (Fischer 1932, 30).

Neskôr, v ére monopolného kapitalizmu a formálnej demokracie, sa individualistický prízvuk slobody presúva na rôzne spoločenské kolektívy, ktoré sa domáhajú rovnosti. Namiesto slobodných individuálnych vôlí nastupujú slobodné kolektívne vôle, záujmy, ktoré ústia do neslobodnej oligarchie „davovo“ organizovaných mocensko-záujmových skupín. Fischer presne opisuje prvú krízu liberálne obmedzenej modernity pri jej prechode do fázy organizovanej modernity. Vtedy občianska spoločnost' v liberálne obmedzených pomeroch zareagovala vznikom národnej a sociálnej otázky. Kríza, v ktorej sa občianska spoločnost’ vtedy ocitla, bola paradoxným vyústením zásad samého liberalizmu, slobody a práva, ktoré boli slúbené indivíduu a stali sa zároveň slobodou pre zakladanie masových hnutí a formálnych organizácií. Začala ich mimoriadne efektívna expanzia, ktorá sa vlastne končí až v poslednej tretine dvadsiateho storočia.

\section{Čo s demokraciou?}

Korene krízy podl’a J. L. Fischera tkvejú v neznalosti poriadku, respektíve v jeho funkčnej poruche, ked' kultúrny prototyp nie je v súlade s poriadkom skutočnosti. Fischer sa pokúša odhalit' ontologické korene tejto krízy. Tvárou v tvár tejto skutočnosti našiel rozpor, v ktorom nás významové štruktúry našej kultúry nútia vydávat' za skutočnost' to, čo skutočnost'ou nie je, ale čo je našou konštrukciou skutočnosti. L'udské úsilie je výpravou za možnost’ami, ktorými je nehotová skutočnost' prekonávaná vyšším a vyšším tvarom. Nemeriame sa budúcimi ciel'mi, ale relativitou súčasnosti, v ktorej je aj skladobná spoločnost' možnost'ou, intelektuálnou konštrukciou, variantom spoločenského vývoja (Valenta 2017, 27).

Fischer kladie otázku: Čo s demokraciou? Čo sa namiesto nej ponúka? Knihu Kríza demokracie píše, ked' Československo po desat'ročí samostatnosti postihla svetová ekonomická kríza. Radikalizovalo sa robotnícke hnutie, demonštrácie (v Košútoch, Moste, Duchcove atd'.) priniesli obete na životoch. Zhrnul desat'ročie vlastných úvah a textov, ktorých jadrom je pojem demokracie. Nerieši dilemu demokracia alebo diktatúra, ale navrhuje položit' otázku aká je demokracia? Možností je hned' niekol'ko: „stereotypná alternatíva: demokracia alebo diktatúra“, ustúpi ovel’a významnejšej: „parlamentná alebo iná, formálna demokracia, alebo iná“. Až po odpovediach na tieto otázky by mohla mat' oprávnenie dovtedajšia alternatíva: demokracia, alebo diktatúra. Takto sa nedozvieme či je diktatúra vhodná, alebo nevhodná. Takýmto postupom sa problém presúva na iné pole a dochádza $\mathrm{k}$ logickej chybe „metabasis eis allo genos“ (Fischer 2007, 738). Je dôležité urobit' toto rozhodnutie, pretože napriek tomu, že 
uznávame kritický stav demokracie, neodmietame ju. Napriek tomu dopyt po kríze demokracie $\mathrm{v}$ diskurze pretrváva.

A zostáva neriešená otázka o praktickej politike, ktorá protirečí demokratickým hodnotám. Demokratickou požiadavkou je, aby jednotlivec nebol pasívnym, ale aktívnym subjektom sociálnych činností, vtedy by bola jadrom demokratickej myšlienky suverenita spoločnosti alebo spoločenská autonómia či „,vláda l’udu“. V marxistickej terminológii je demokracia dôsledkom „triedneho uvedomenia“. V takomto výklade sa demokracia stáva nevyhnutnou, iný režim je nemožný. K odcudzeniu demokracie dochádza vo vzrušených obdobiach „sociálneho nepokoja, ked’ sa suverénom stáva vláda, ktorá sa teší podpore širokých sociálnych vrstiev. Ak sa táto požiadavka nenaplní, dochádza ku krátkodobým prejavom teroru, úspešného iba vtedy, ked spoločenské vrstvy, proti ktorým je namierený, stratili v malátnom ochabnutí svoje sebavedomie“ (Fischer 2007, 739). Fischer d’alej uvažuje o podmienkach, za ktorých dochádza $\mathrm{k}$ takýmto výnimočným režimom. Zistil, že je ním vyvolaný nepomer medzi danými sociálnymi tendenciami a danými sociálnymi inštitúciami. Každý sociálny útvar je výsledkom adekvátnej objektivizácie sociálnych tendencií, ktoré sa postupne autonomizovali a odcudzili svojmu funkcionálnemu určeniu. Svoju filozofiu charakterizoval ako funkcionálny racionalizmus. Podstatným rysom je „skladobná intencia“ ako apriórna zložka poznania. To je dôvod postulovania definícií s dispozíciou postihnút' aj krízu demokracie. Jeho analýza demokratických postulátov napokon vyústila do skladobnej, štrukturálnej demokracie.

Nepomer sociálnej oblasti a spoločenského vedomia teda identifikuje ako kritický stav. Riešením je opätovné nastolenie sociálnej rovnováhy. Typickým znakom novovznikajúcich sociálnych tendencií je ich neurčitost', difúznost', afektivita, a ked' chýbajú prostriedky nápravy a kríza sa prehlbuje, afektivita umožňuje vznik davových hnutí o to radikálnejších, o čo ideovo bezradnejších (Fischer 2007, 740).

Protidemokratické prúdy, ktoré sa obhajujú diktatúrou, sú svedectvom programovej bezradnosti. Fischer navrhuje oslobodit’ sa od „afektívneho prekliatia“. Západoeurópske krajiny t’ažili v týchto súvislostiach $\mathrm{z}$ demokratických skúseností s premenou sociálnych vzt’ahov. Alternatíva: parlamentná demokracia či iná konštelácia chýbajúcej demokratickej praxe zväčšuje chaos a môže dôjst' $\mathrm{k}$ vyradeniu demokratických princípov. No iba od demokracie samej závisí, či sa presadí. Je však chybou parlamentnej demokracie, ked' demokratická prax neponúka pozitívne prostriedky riešenia. „Potom by odtial’ vyplynul iba jediný záver, že demokracia je odsúdená k zániku, teda opak toho, v čo veria stúpenci parlamentnej demokracie... Ale existuje skutočne takéto bytostne vnútorné spojenie demokracie s parlamentarizmom?" (Fischer 2007, 740). Fischer konštatuje, že novo zriad'ované demokracie iba prevzali staršie parlamentné vzory a obmieňali ich. Dá sa teda predpokladat', že demokracie si môžu 
vytvorit' nové inštitúcie, ktoré by jej vyhovovali, tak ako predtým parlamentarizmus. Teoreticky je to možné, ale aby to bolo aj prakticky uskutočnitel'né, treba preskúmat' príčiny politickej a sociálnej krízy (tridsiate roky minulého storočia), aby sme vedeli, ako sa pokúsit' o nápravu.

Fischer považoval vtedajšiu demokratickú prax iba za jednu vrstvu mechanického kultúrneho vzoru, ktorým doznieva epocha západoeurópskeho vývoja. Teória tohto mechanického typu chápala skutočnost' ako sumu rovnorodých kvantitatívnych častí, pričom ich vzt'ah určila neosobná kauzalita ako mechanický dôsledok tohto kauzálneho nespojitého ret'azca. Takýto prístup teoretického mechanizmu zatomizoval skutočnost', podriadil ho moci slepých prírodných síl; a ak sa podobná atomizácia týka politického mechanizmu (poriadku) ako mechanického výsledku „spočítaných politických prejavov", tak programom dnešnej demokracie je nemat' program, uzatvára Fischer (Fischer 2007, 743).

Fischer pokladá politickú skutočnost' iba za jednu stránku sociálnej skutočnosti. Sociálny mechanizmus charakterizuje prevaha autonómnych hospodárskych zretel'ov nad inými, aj sociálnymi. Vzhl'adom na túto skutočnost' Fischer vníma spoločnost' v kapitalizme ako sociálny poriadok, v ktorom „statky fundujú hodnoty a výrazy“. Hospodárstvo určuje hodnoty a tvorbu. Táto kvantitatívna mechanická dogma má za dôsledok neosobné pôsobenie sociálnych síl. Pre politiku to znamená prevahu záujmov, moci, až po neschopnost' sociálne čelit' kapitálu. Centrom všetkých týchto tendencií je parlament, ktorý nedokáže čelit' kapitálu. Prevažujú politické záujmy, ktoré mechanicky kopírujú záujmy kapitálu. Základný demokratický postulát, aktívna spoluúčast' všetkých členov spoločnosti, sa redukuje na formálne akty, väčšinou volebné.

Kapitalizmus si vo svojom vývoji nezadržatel'ne prisvojuje demokratický postulát a dopláca na to demokratická prax. Najdôležitejší poznatok, ktorý Fischer vyvodzuje, je ten, že kapitalizmus a demokracia sú navzájom nezlučitel’né. A pokračuje d’alej, kapitalizmus aj demokratická prax v kapitalizme sú iba jednou zo stránok ovel’a hlbšej skutočnosti mechanického kultúrneho ,prototypu“. Preto na ozdravenie demokracie nestačí pád kapitalizmu, ale je potrebný nový, vyšší štrukturalistický kultúrny „prototyp“. Treba sa zbavit' tieňov minulosti, udržat' tvorivost', až potom sa obnoví aj myšlienka demokracie. To je však podstatná zmena a Fischer, ako uvidíme, ide ešte d’alej ako E. Beneš. Na záver prvej časti štúdie Co s demokracií?(Fischer 2007, 742) položil otázku, ako mohla vzniknút' demokratická myšlienka v kapitalizme, ked' je s ním v rozpore, v protiklade. Odpovedá historickým argumentom. Demokratická myšlienka bola argumentom „tretieho stavu“, jeho nároku, ktorý bol predtým stavovským zriadením v spoločnosti vylučovaný z politickej účasti. Vyššie sebavedomie buržoázie bolo obmedzené len na tretí stav a smerom k hospodárskemu liberalizmu, 
ktorý je však typickou črtou kapitalizmu. Až postupne, vývojom sa liberálna demokracia mení na sociálnu demokraciu s požiadavkou rovnosti politických práv pre celú spoločnost' (Fischer 2007, 742). Fischer má výhrady k politickým stranám, uprednostňuje pred nimi hnutia. V českom prostredí je to diskutovaná téma. M. Pauza pripomína Fischerovu výhradu voči Masarykovi, v ktorej odmieta jeho tézu o „demokracii ako diskusii“, ktorá sa nemá týkat’ politických strán (Fischer 2007, 74). Fischerovi etická koncepcia demokracie nestačí, Masarykov pokus považuje za neúspech.

Pravda, aj Masaryk bol v tejto oblasti kritický, ale ako správne upozorňuje M. Pauza, pozornosti uniká Benešov spis Strannictví: sociologická studie (Beneš, 2013). Podla Pauzu chýba kritická analýza Benešovej knihy, v čom má bezpochyby pravdu. Približme si Benešov pohl'ad na politické strany a na dobu, ktorú súčasná sociológia charakterizuje ako nástup organizovanej modernity.

Beneš začína svoju analýzu organizovaním davu a tvorbou strán v davoch. $\mathrm{Na}$ to, aby dav konal a rozhodoval, je dôležité, aby sa organizoval. Beneš hovorí o vnútornej organizácii davu, ktorá je kolektívnou vôl'ou a uvedomením. Vonkajšia organizácia davu je v činnosti jednoducho tým, že priame konanie, akcia sa nedá realizova, čomu zodpovedá delegačný princíp. Beneš sa odvoláva na Simmela, ktorý v zastupovaní vidí pud sebazáchovy (Beneš 2013, 18). Ale pozná aj Michelsove argumenty. Beneš rozoznáva neorganizovaný, čiastočne organizovaný a úplne organizovaný dav (Beneš 2013, 20). Kam by zaradil Beneš dnešnú priamu demokraciu organizovaných záujmov? Benešov pohl'ad na dav, masu, však nie je pohl'adom dnešnej sociológie. Ním je pohl'ad J. S. Milla, ktorý v eseji $O$ slobode napísal ,avšak teraz spoločnost' získala vrch nad individualitou a nebezpečenstvo, ktoré z tohto hrozí l'udskej povahe, nie je nadbytok, ale nedostatok osobných pohnútok a túžob (Mill 1995, 94).

Fischer sa neuspokojil s odpoved'ou na otázku: „Aká demokracia: formálna či iná?““ a tvrdí, že analógiou dostávame vyhrotenú otázku: „Kapitalistická spoločnost' či iná?“. Proti takémuto výkladu ponúka inú orientáciu: štrukturálnu (skladobnú) demokraciu. Jej základné princípy sú protipólom kapitalistickej spoločnosti. Aby nedošlo k nedorozumeniu, Fischer sa ohradzuje najmä proti možnému omylu, ktorým je rozdiel medzi štrukturálnym poňatím a vtedajšími názorovými a politickými smermi, ktoré označil ako protikapitalistické. Fischerov pojem funkcie sa nekryje s jeho metodologickým výkladom. Jeho snahou bolo vytvorit’ taký pojem funkcie, ktorý by sa dal uplatnit' a ktorý by zároveň vyhovoval jeho zámeru vystupovat' proti kvantifikujúcim tendenciám novovekej vedy (Valenta 2017, 214).

Fischer navrhuje väzbu organizácie s programom, ktorá sa pravdepodobne líši od vtedy bežných demokratických postupov a zdôraznil, že tento stav spôsobuje a spôsobil neúčinnost' demokratických režimov a opätovne zopakoval tézu, že kapi- 
talizmus a demokracia sa vylučujú. Kapitalistická výroba pre výrobu, ovládaná motívom zisku, má nahradit' výrobu pre potreby na základni sociálneho optima. V niektorých ohl'adoch môže slúžit' ako vzor, hoci iba podmienene, sovietske Rusko. Fischer si uvedomuje samozrejmé t’ažkosti pri zavedení tohto prístupu, najmä dnes vyznievajú paradoxne, vie, že ideálne uplatnenie jeho návrhu štruktúrnej zmeny, v ktorej hodnoty formujú hospodárstvo, bol vtedy uskutočnitel'ný iba autarktne, uzavreto. Paradoxne však predpokladá vel'ké súrodé kontingentné celky v rámci svetového hospodárstva. Tento pohl'ad sa blíži až k dnes rozšírenému konceptu otvorenej spoločnosti. Fischerov štrukturálny (skladobný) prístup ruší autonómny charakter hospodárskych činností.

Výklad pokračuje približením fungovania štrukturálnej hierarchie jednak správnej, vrcholiacej vládou, a korporatívnej, v podobe syndikátov, ktoré plnia sociálne funkcie. Tento postup vrcholí v sofokracii. Cítit’ tu ovplyvnenie Platónom, ale výslednicou jeho úvah je hierarchia: kapitalistická spoločnost', socialistická spoločnost', spoločnost' sociokratická. Ako konštatuje M. Pauza, Fischer koncipuje vyšší politický ideál ako socializmus: sociokraciu. Je to protiklad k Masarykovmu individualistickému poňatiu demokracie. Dodáva však, že na rozdiel od Masarykovho náboženského a etického východiska je jeho prístup sekulárny a racionalistický. Každá doba vytvára svoj vlastný slovník, „dobové ladenie“. Do takýchto slovníkov vrastáme a prirodzene ich do seba vstrebávame. Fischer za začiatok takéhoto prístupu označil svoju prácu Über die Zukunft der europäischen Kultur, vydanú v Mníchove v roku 1929. Tento stav označil ako „mechanistický kultúrny prototyp“, ktorého stav súvisí s rozvojom modernej prírodovedy a po politickej a hospodárskej stránke s rozvojom kapitalizmu. Skutočnost' v tomto zmysle je zdôvodnitel'ná iba ako extenzívna, rozl'ahlá (a preto meratel'ná). Protikladom sa stal subjekt ako zvrchovaný rozhodca v otázkach pravdy (Fischer 1967, 14). Bola vyhíbená taká hlboká priepast’, že subjekt stratil svoje „občianstvo k prírode“ (Fischer 1967, 14). Predstava, ktorá sa tu zrodila a bola vyjadrená „mechanickou kauzalitou“, kvantitatívne rozrôznenou, obsiahla svojimi dôsledkami všetky l'udské horizonty, odsúdiac ich k „,bezzmyselnosti“ ako posledné slovo vedy. Analogickou posadnutost'ou kvantitou, $\mathrm{v}$ tomto prípade ekonomickou, finančnou, bol zasiahnutý kapitalistický poriadok, ktorý si vytvoril vlastnú nevyhnutnost' autonómne docielit' maximum ekonomických hodnôt a podriadit' svojmu imperatívu ostatné spoločenské dianie (Fischer 1967, 14).

Fischer vidí skutočnost' ako jednotný, zložito diferencovaný a hierarchizovaný celok anorganična, organična, sociálna, duchovna a sakrálna. Skutočnost' „kvalitatívne rozrôznená“ do existenciálnych módov (,skutočnostných sfér“, „tvarov“, „,eelkov“, „kvalitatívne vyššie“ sa vynára z „,nižšieho“), pričom vyššie si uchováva svoju 
autonómiu. V tomto vertikálne členenom svete bolo l'udské snaženie orientované nahor a je tragédiou, že človek napodobnil svet mechanizmom, ktorý sa naučil konštruovat' ako „stroj“. Pauza hovorí o horizontálnom členení. V tomto poňatí je demokracia zriadenie, ktoré je natol'ko krehké, že je súčasne vrcholom kvalitatívnosti, a zároveň objektom zneužitia. Fischerova ,skladobnost“", štrukturalizmus, je tak aj obavou o osud západnej európskej civilizácie a osobitne demokracie (Pauza 2019, 237). No ako Pauza vo svojom magnum opus Idea strukturálni demokracie dodáva, Fischer nezdiel’a Masarykovo presvedčenie, že pri presnej filozoficko-ontologickej základni (teda nie pri obyčajnej masarykovskej istote, že Prozretel'nost' nakoniec spolahlivo a nevyhnutne presadí svoj Plán) možno kríze demokracie účinne čelit' (Pauza 2019, 237). Demokracia je pre Masaryka „aristokratizmus“ sekulárnej občianskej individuality. Fischer ponúka radikálne inú reflexiu, ktorá sa odlišuje od kapitalistických princípov, parlamentarizmu a pojmovo je vyjadrená ako ontologicko-noetický základ funkcionálnej (,skladobnej“) filozofie. Fischerov ontonoetizmus je konfrontovaný s Masarykovou ontoteológiou.

Okolnosti formovania ontonoetickej koncepcie demokracie približuje v Listoch o druhých a o sebe (Fischer 2005). Najviditel'nejším symptómom bola rapídne narastajúca nezamestnanost', pričom jej pochopitel'ným dôsledkom boli obranné reakcie robotníkov, potlačované najbrutálnejšími prostriedkami. Nemenej bolestným symptómom nezamestnanosti aj nerobotníckych vrstiev je predovšetkým nezamestnanost' celej dorastajúcej mladej generácie, pre ktorú doslova nebolo miesta. Hned' potom, ked' vyšla Kríza demokracie (1933), podl'a Listov o druhých a o sebe jeden z hostí hotela v Brne na znamenie protestu vyhodil do povetria nielen seba s milenkou a dietat'om, ale celé jeho krídlo, v ktorom sa odhodlal k tomu zúfalému kroku (Fischer 2005, 341).

Ak bola sociálna skutočnost' rozvrátená, na vine bol aj nedostatok dobrej sociálnej teórie... „Pokúsil som sa o to svojou Krízou demokracie, konkrétne Predbežnými skúmaniami $\mathrm{k}$ druhej knihe. $\mathrm{V}$ tom, súdim, je tiež najväčší prínos knihy. $\mathrm{V}$ tom je jej aktuálnost' i dnes, respektíve ešte dnes. O jej aplikáciách na vtedajší stav však platí, že síce osvetl'ovali tento stav s pomerne vel'kou presnost'ou, že by však museli byt' doplnené rozborom všetkých tých štrukturálnych zmien, ku ktorým došlo od tej doby v priemyslových spoločnostiach. Poviem o nej ešte len, že je až doteraz mojou najlepšou knihou, uliatou akoby z jedného kusu, a že je to tiež prvý pokus o sústavné zdôvodnenie zásad socialistického humanizmu... Tak som bol presvedčený o správnosti a preukázatel'nosti svojich riešení, že - nepochyboval som o tom ani okamžik celý svet sa im podriadi, bude musiet' sa mu poslušne podriadit'. Bola to zlá pýcha, skutočná ,hybris‘, spupnost', čo v očiach starých Grékov označovalo najt’ažšie previnenie, ktorému mohol človek prepadnút'. A ktoré vzápätí prinieslo najt’ažší trest“" (Fischer 2005, $341-342$ ). 
V prístupoch a reflexii o demokracii sa často rozlišuje context of discovery, koncept bádania a concept of justification, koncept zdôvodnenia. Ten druhý pre Ameriku vedecky zdôvodnil Max Wertheimer a neskôr po ňom metateoreticky Robert Dahl, na základe „pevnej zásady rovnosti“, ktorá je predpokladom všeobecného, rovného a tajného hlasovacieho práva. Hoci vieme, že l'udia si reálne rovní nie sú (Valenta 2017, 42).

Už pre Krízu demokracie je typický Fischerov termín „skladobný“, syntetický prístup. Práve tu môžeme sledovat', ako sa jeho koncepcia integrálnej spoločnosti, holokracie a štrukturálnej demokracie nakoniec stala iba nenaplneným snom novej spoločensko-správnej hierarchie (Pauza 2019, 797). Občania (zostali) s možnost’ami a rizikami - odborníci - vláda s odbornými poradcami. Vláda predkladá program (referendum). Ak nie je prijatý, vláda rezignuje a proces sa opakuje. Okrem vlády s mocenskými kompetenciami existuje aj duchovná moc produkujúca idey. Výslednicou je spoločnost' s novou úrovňou života.

\section{Žiadna historická premena?}

Fischer rozlišuje „dva póly“ demokracie, alebo dva spôsoby utvárania politickej funkcie - anataktický (zospodu nahor) a katataktický (zhora dole). Medzi nimi existujú prepojenia spoločenských vrstiev. Tento prístup vylučuje monokoncepciu demokracie.

Metodologickým predpokladom pre výklad „sociálneho diania“ je pojmové určenie spoločnosti. Vymedzuje ju ako sústavu sociálnych funkcií, ako záujmami podmienenú tendenciu, ktorá vytvára určité nástroje, a tie skutočnost’ objektivizujú. Súčet individuálnych záujmových zretel’ov nepostačuje, preto sociálne funkcie navodené záujmami produkujú sociálne súcno. Z množstva vzt’ahov Fischer vyčlenil dva: organizáciu a zriadenie (ako príklady uvádza štátnu organizáciu a právne zriadenie). Organizačné a inštitucionálne väzby sa navzájom líšia extenzívne i intenzívne. Intuitívne opísal konkrétnu formu organizačného konsenzu - štát (Fischer 1933, 16). Charakteristickým znakom sociálneho súcna je autonómia, relatívna nezávislost' od spoločenských subjektov. Určujúcou tendenciou je dosahovanie už spomenutého funkcionálneho optima (Fischer 1933, 16). Rozsah štrukturálneho a organizačného konsenzu sa nemusí kryt'. Podmienkou štrukturálneho konsenzu je konsenzus záujmov, ktorý je dynamický. Spoločnost' nie je iba objektívna realita, ale sociálne súcno je zároveň v dosahu ideologických činitel'ov. Ideológia je transkripcia objektívnej skutočnosti vo vedomí, preto sociálna ideológia je prepisom sociálnej skutočnosti (Fischer 1933, 18). Teoretický vzt’ah k skutočnosti je neosobný, teoretický a „telický“, na báze záujmov. Výsledkom prvého vzt’ahu sú poznatky a druhého hodnoty. „Súbehom“ oboch sú názory. 
Kompozične Fischer postupuje aj d’alej: štrukturálnu jednotu vytvára názorový konsenzus. Ideológie sa mu javia ako dôsledok, nie ako „primárny agens“ (Fischer 1933, 19), ale podmienkou ich účinnosti je, aby mali „ontický základ“ (Fischer 1933, 20). Kompozične potom názorové syntézy „produkuje“ filozofia a základnú vývojovú spoločenskú epochu môžeme vyjadrit’ „kultúrnym prototypom toho, onoho obdobia“. Poruchy sociálneho konsenzu sa preto spočiatku prejavia v oblasti názorov. Preto je dôležité tieto prekážky zvládat' ideologicky. Napokon sa Fischer dostáva k otázkam slobody, k téme našich možností pretvárat' skutočnost'. Záleží od našej odhodlanosti, od nášho heroizmu, aký dokonalý poriadok sme ochotní uskutočnit' (Fischer 1933, 22). Teoretické zvládnutie skutočnosti nám na tejto ceste kladie najmenej prekážok.

Priestor pred Epilógom J. L. Fischer zaplnil exkurzmi do dejín politického myslenia. Propozičné a pojmové postoje opiera o kontexty. Vo vývoji demokratickej idey zohrala dôležitú úlohu myšlienka suverenity spoločnosti. Suverenity sa dovolávajú korporácie, ktoré sa považovali za predstavitel'ov celej spoločnosti voči panovníkovi, ktorý sa predstavuje s rovnakým nárokom ako suverén celej spoločnosti. Argument je namierený proti vládnucemu absolutizmu nie v mene demokratického, ale stavovského zriadenia, ktoré by svojou autonómnost'ou bolo oponentom král'ovskej, respektíve panovníckej moci. Takto chápaná suverenita spoločnosti sa javí ako regres. Ideologicky však priniesla niekol'ko prvkov, ktoré sa ukázali ako dôležité pre potvrdzovanie demokratickej myšlienky.

Najvýznamnejšou sa stala fikcia spoločenskej zmluvy s biblickými koreňmi (Fischer 1933, 49). Stavovské revolty proti panovníkovi sa odvolávajú na najradikálnejšie názory „monarchomachov“ $s$ právom zavraždit’ ho. Sociálne a triedne revolty sú známe v protestantských, ako aj v katolických komunitách. Idea demokracie, ktorá sa presadila, má dve podoby: lockovskú - s obhajobou slávnej anglickej revolúcie a rousseauovskú, ktorá je predohrou Vel'kej francúzskej revolúcie. Anglický individualizmus ponúka iný prístup ako francúzska kontinentálna občianskost'. Fischer vie, že Lockovi nejde o slobodu a rovnost', ale o práva majetných vrstiev (Fischer 1933, 59 - 60). Lockovský prístup je kvantifikujúci, „merajúci“ rozum v novovekej západnej spoločnosti. S Rousseauom Fischer bojuje a z jeho chýb aj vychádza. Locke bol liberál a Rousseau egalitár. Odtial' anglický decentralizmus a zvykové právo so sebavedomou anglickou empiričnost'ou, a na druhej strane francúzsky racionalizmus so systematickým právnym kódexom a prísne scentralizovanou byrokraciou a nedotklivost'ou, ktorá sa dokáže podriadit' poriadku len z autonómneho rozhodnutia (Fischer 1933, 74 - 75).

Pozoruhodný je však záver, ku ktorému Fischer dospieva. V dnešnej dobe všeobecnej krízy autorít akceptujeme, že ideálna demokracia ani ideálna spoločnost' nee- 
xistujú. Vrcholom kompetencií je „spontánna autorita“, jednota odbornosti a múdrosti. Nemožno ju nariadit', ani demokraticky odvolat'. Autorita nie je hospodárskym ani politickým zretel'om, ale kultúrnym. Končia sa politické triky a aritmetika volieb. Sme na prahu „král’ovstva duchovnej moci“ a konca svetskej každodennosti. Elitou je spoločnost', nie jej čast' alebo jednotlivec. Takto sa zrodí priestor socialistického humanizmu. Pozornost' by si ale v tomto kontexte bezpochyby zaslúžil výklad pojmu zretel' (Fischer 2007, 746 - 750, 754, 755). Nastáva koniec davového človeka s jeho expanzívnym egoizmom.

Napokon vlastný kritický odstup čítame v epilógu: tretí mýtus. Prvým je mýtus zakotvený v bohu, mýtus ducha božieho, mýtus stredovekého sveta. Druhým mýtom bol mýtus novovekého sveta, zlomený heroickým úsilím titanov, ktorý zmenil pyšného tvorcu na bezmocný atóm a hračku slepých síl - mýtus ducha tiaže. Tretím je mýtus skladobného sveta, ktorý spútava rozpútané slobody a podriad’uje ich kvalitatívne stupňovanému poriadku. Na jednej strane určuje smer, ale na druhej strane ukladá človeku plnú zodpovednost' za jeho bytie a žitie. Obdaril ho pokorou, ale uložil ciele spolutvorit' poriadok skutočnosti - spoluvytvorit' - mýtus tvorivého ducha.

Valenta si u Fischera všíma blízkost' českého a rakúskeho politického a filozofického myslenia (Witgenstein, Viedenský krúžok) a aj vzhl’adom na iné osobnosti (Brentano, Bolzano, Masaryk) sa môže hovorit’ o stredoeurópskom myslení (Valenta 2017, 34). Fischerova kritika pozitivizmu, najmä koncepcie dát bezprostrednej skúsenosti a domnelej bezpredpokladovosti, má svoje opodstatnenie aj v súčasnosti (Valenta 2017, 89).

Fischer sa o symbolickú logiku zaujíma od pät'desiatych rokov minulého storočia. Z modernej logiky je mu najbližšia intenzionálna logika s pojmom striktnej implikácie, väzba medzi logikou a jazykom a logikou a skutočnost’ou. Nedocenil však možnosti, ktoré ponúka symbolická logika filozofickému mysleniu. Súčasná logika nezohrávala vo Fischerovej koncepcii také miesto, aké získala a obhájila v analytickej filozofii (Valenta 2017, 90).

Fischerovo úsilie vrcholí v jeho konceptuálnej konštrukcii skutočnosti, o ktorú sa nepokúsila ani novopozitivistická, ale ani analytická filozofia. Bol to pokus o „nový racionalizmus" blízky A. N. Whiteheadovi, G. Bachelardovi, či B. G. Kuznecovovi. Valenta pripisuje Fischerovi skrytý, alternatívny program analytickej filozofie (Valenta 2017, 90).

Sofokracia je možný svet so svojou intenzionálnou bázou. Otvoreným problémom je stav sveta $v$ danom čase, nevyhnutné je poznanie jednoznačného determinačného systému. Rovnako otvoreným problémom je, že nedokážeme určit’ tie elementárne kritériá, ktoré považujeme za prvky intenzionálnej bázy. Každý svet je logicky možný, teda aj sofokracia. Sociokracia nemôže byt' zároveň socializmus. Otázkou 
ostáva, aký je aktuálny svet. „Fischer je sociálnym humanistom l'avicového razenia“ (Pauza 2019, 797).

V brožúre Únor 1948 v Slove $k$ vychovávatelom sa v záverečných pasážach venuje téme, ktorá je stále aktuálna. Je to živelný záujem o to, aby dorastajúca generácia vrástla nielen odbornou prípravou, ale predovšetkým svojím zmýšl’aním do spoločného národného a štátneho úsilia. Ked' sa z tohto hl'adiska zamýšl’a nad inteligenciou, najmä mladou, má z obrazu, ktorý sa mu ponúka, vel'kú úzkost'. Úzkostlivo sa pýta na budúcnost' tohto štátu, keby sa generácie, ktoré budú postupne preberat' nimi budované dielo do svojich rúk, postavili negatívne $\mathrm{k}$ tomu, o čo sa ich predkovia usilovali. Viete si predstavit', aká by to bola tragédia pre národ a štát? A uvedomujete si, kto je vlastne sol'ou tejto mladej krajiny, týchto dorastajúcich generácií? Vychovávatelia sú zodpovední pred národom a dejinami (Fischer 1948, 20 -21). Predtým Fischer vecne zhodnotil Február 1948 s poznámkou, ktorá platí, mimochodom, aj dnes. Fischer triafal do čierneho, ked' to vnímal ako výsledok pôsobenia geopolitických, či geostrategických síl.

Fischer vystihol problém v analýze krízy demokracie, ktorý vzniká „prevahou kvantitativne-mechanických zretel'ov a nespojitostí kultúrnych útvarov" (hospodárskeho, spoločenského a hodnotového). Riešenie vidí v nahradení nespojitosti skladobným princípom s novou kultúrnou orientáciou (vrátane nových inštitúcií). Súčasná politická filozofia nadväzuje na Fischera - kríza kapitalizmu (liberalizmu) vedie k hl'adaniu novej spoločenskej zmluvy o fungovaní - demokratickej [...] spoločnosti (Dennen, 2019). Preto neprekvapuje, že v tejto situácii sa objavuje úsilie o zvládnutie krízy demokracie aj prostredníctvom novej artikulácie vzt’ahu medzi liberalizmom a demokraciou. Avšak objavil sa aj priestor pre postliberálnu konšteláciu obrany demokracie. Vplyv získali deliberatívna a hybridná verzia demokracie, neorepublikanizmus, ale aj hl'adanie nového spôsobu, ako zmierit' liberálnu demokraciu a socializmus až po postštrukturalistickú radikálnu demokraciu. Fischer bol filozof, nebol politik, ale jeho hlas znie aj dnes a duch tiaže nás stále neopustil.

\section{Literatúra}

BECK, U. (2004): Riziková společnost. Praha: Slon.

BENEŠ. E. (2013): Funkce politických stran. Praha: Společnost Edvarda Beneše.

ČERNÍK, V., VICENÍK, J., VIŠŇOVSKÝ, E. (1997): Historické typy racionality. Bratislava: Iris. DENEEN, P. J. (2019): Proč selhal liberalismus. Praha: Academia.

DUFEK, P., BAROŠ, J., BLÁHOVÁ, S., KŘEPELOVÁ, T., TAUFAR, P. (2019): Liberální demokracie v době krize: perspektiva politické filosofie. Praha: Slon.

FISCHER, J. L. (2007): Co s demokracíi? In: Výbor z díla, I. Olomouc: Academia, Univerzita Palackého v Olomouci, $738-755$.

FISCHER, J. L. (1968): Funkcionalismus a strukturalismus v české filosofii a sociologii. In: Sociologie '66. Praha: Svoboda. 
FISCHER, J. L. (1933): Krise demokracie. Brno: Knihtiskárna Typia.

FISCHER, J. L. (1967): Kvalitatívní kosmos. Filozofia, 22 (1), 12 - 27.

FISCHER, J. L. (2005): Listy o druhých a o sobě. Praha: Torst.

FISCHER, J. L. (1929): Über die Zukunft der europäischen Kultur. Drei Masken. München: Drei Masken Verlag.

FISCHER J. L. (1948): Únor 1948. Slovo k vychovatelim. Praha: Orbis.

MILL. J. S. (1995): O slobode. Bratislava: Iris.

PAUZA, M. (2019): Idea strukturální demokracie. Politická filosofie na principu respektu k Řádu skutečnosti. Praha: Filosofia.

VALENTA, L. (2017): Česká filozofie. Sebrané spisy I. Olomouc: Univerzita Palackého v Olomouci.

ZNOJ, M., BÍBA, J., VARGOVČÍKOVÁ, J. (2014): Demokracie v postliberální konstelaci. Praha: Karolinum.

Stat' je výstupom grantu VEGA 2/0152/20 Tendencie vývoja súčasného kapitalizmu-protirečenia a konflikty.

Jozef Lysý

Univerzita Komenského Bratislava

Pedagogická fakulta

Katedra etickej a občianskej výchovy

Račianska 59

81334 Bratislava

Slovenská republika

e-mail: lysy@fedu.uniba.sk 